\title{
Anatomiscal Consideration of "Artav-vaha Srotas"
}

\author{
Ashok kumar Sharma* and Manisha \\ Assistant professor, Rachana Sharir, A \& U Tibbia College Karolbagh, India
}

Submission: September 01, 2017; Published: September 12, 2017

*Corresponding author: Ashok kumar Sharma, Assistant professor, Rachana sharir, A \& U Tibbia college Karolbagh, Chaudhary brahm prakash ayurvedic charak sansthan dabar khera najafgarh, New Delhi-43, India, Email: asdrbhalsharma@gmail.com

\section{Abstract}

Ayurveda is most ancient medical science having all the part of medical including anatomy, physiology, pathology, medicine etc. brief anatomical description of human body is given in Sharir- sthan of every text of Ayurveda. Srotasas are the peculiarity of Ayurvedic medical science describing the systems of body. Srotasas are considered as secretary channels [1] of the body. Srotasas are the hollow spaces of our body which transport the parinam prad dhatu [2] (essence of the food) from one place to another place. Srotasas are the systems or the part of the body systems or the secreatory channels which are responsible for the secretions or transportation of Dhatus. Purush (Live being) is considered as the combination of Srotsas [3].

According to Acharya Shushrut there are two roots of Artav-vaha srotas, Garbhasaya (uterus) and Artav - vaha dhamani [4]. Here artav-vha srotasis antermukh srotas which is also known as yogvahi srotas. Here Artava is the menstrual blood and Artav vaha Srotas is the part of female reproductive system which is responsible for the formation of menstrual blood and the passage which carry the menstrual blood during menstrual cycle. We can consider all the systems including hormones secretory glands which are responsible for the formation of menstrual blood and its mensuration at right time eg. Ovary and its follicle. Due to the injury in Artav vaha srotas infertility, sexual intolerance, amenorrhea symptoms can be seen. In last Artav vaha srotasa may be considered ovary, uterus, uterine endometrium, uterine arteries, cervix, vagiana etc

Keywords: Srotas; Artav; Garbhashaya; parinamprad dhatu; Artava vaha dhamani; yogvahi

\section{Material and Method}

It is a review article, in which I want to elaborate the ancient rachana sharir part Srotas in the light of modern anatomy. Various Acharyas in ancient era mention the topic Srotas sharirbut in this article I would like to focus upon the main text of ayurveda, charak and shushrut views regarding the Srotas. Two type of Srotsas are described here Bahirmukh Srotas [5] (opens outside) and Antarmukh Srotas (opens inside the body). Here artav-vha srotasis antermukh Srotas which is also known as yogvahi srotas.

If any injury occurs in artav vaha Srotas then vidd lakshana [6] (symptoms due to injury) are the infertility, amenorrhea, painful intercourse etc.

\section{Discussion}

Roots of artav-vaha Srotas mentioned Garbhashaya and Artav vaha dhamani. Garbhashaya is the uterus or womb which is the reservoir of artava (menstrual blood) in the endometrium till the date of menturation. According to acharya shushrut the position of Garbhashaya is in the third whorl of yoni (vagina) and its shape is like rohitmatsya much (rohu fish). Acharya Dalhan says that the opening is narrow and cavity is very large in shape
[7]. Endometrial of uterus is the main reservoir of the artava eg. Menstrual blood. During the menstrual cycle proliferation of the endometrium occur and the blood supply increases. The uterine arteries are the main vessels for the endometrium supply.

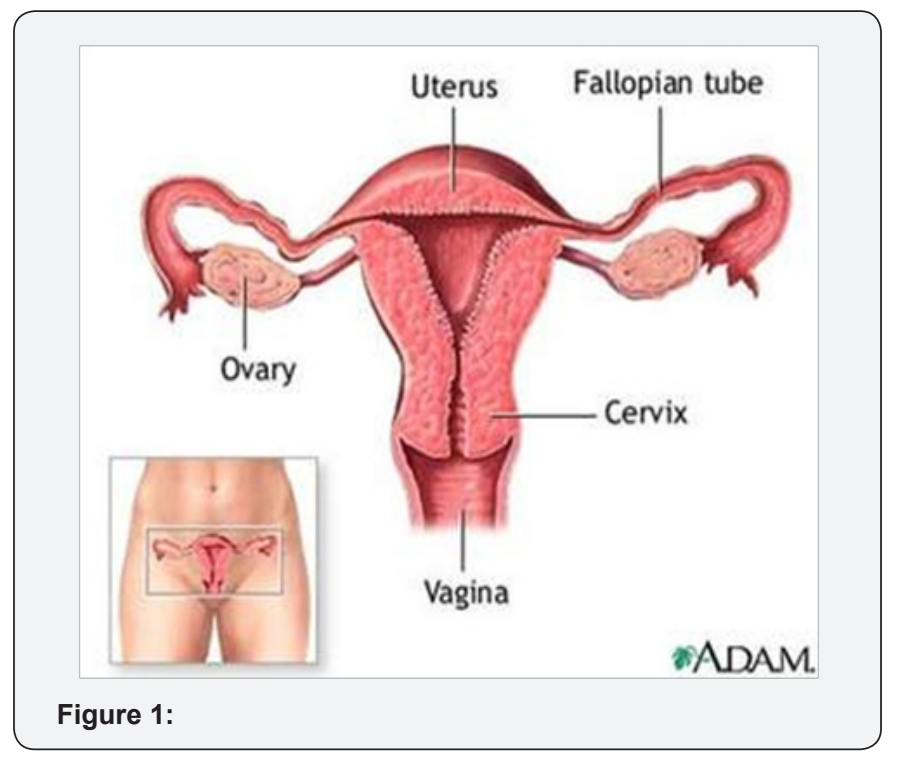


Here the artava formation is done under the influence of the estrogen and FSH. The hormones are secreted by the pituitary and ovary are also the part of artava vaha srotas. When mensuration occurs the flow of artava is through uterine cavity toward the cervix and vagina. Here uterine cavity, cervix and vagina is also the artava-vaha damani (passage) which is the root of artava-vaha srotas. Finally we can consider as artav vaha Srotas to the whole female reproductive system [8]. Due to the injury in any part of artav vaha Srotas there may be infertility, amenorrhea and pain during sexual act. It may happen due to the injury of uterus, uterine tubes, vaginal wall, cervix and their surrounding viscera (Figure 1).

\section{Conclusion}

Reviews as per my study through the ancient Srotas sharir wsr to artava-vaha Srotas and its anatomical consideration with modern anatomy it come to know that whole female reproductive system is considered as the artav vaha srotas. Though opening of the vagina is considered as Bahirmukh Srotasbut that is also a part of artava vaha Srotas that is yogvahi srotas. Mainly the endometrium, uterine and ovarian vessels, and hormone secretory glands are the roots of artava-vaha srotas.

\section{References}

1. Agnivesh, charak, vidhotini, chaukhamba, ch. shutra 30 , ver.12, p. 554.

2. Agnivesh, charak, vidhotini, chaukhamba, cha. Viman 5, ver 3, p. 709.

3. Agnivesh, charak, vidhotini, chaukhamba, cha. Viman 5, ver 4, p. 709.

4. Vriddh shushrut, shushrut, Ghranekar comm., shu.sha., ch.9, ver.22, p. 243.

5. Vriddh shushrut, shushrut, dalhan comm., nibandh sangrah, shu.sha., ch.9, ver.12, p. 386.

6. Vriddh shushrut, shushrut, Ghranekar comm., shu.sha., ch.9, ver.22, p. 243.

7. Vriddh shushrut, shushrut, dalhan comm., nibandh sangrah, shu.sha., ch.9, ver.12, p. 386.

8. Gray's anatomy, peter \& roger, edi 37, ELBS, ch.8, p. 1436. 